\title{
New Trends in the Treatment of Bone Metastasis
}

\author{
Evan T. Keller, ${ }^{*}$ Jinlu Dai, June Escara-Wilke, Christopher L. Hall, Kathleen Ignatoski, \\ Russell S. Taichman, and Jill Keller \\ Department of Urology, University of Michigan, Ann Arbor, Michigan 48109
}

\begin{abstract}
Bone metastasis is often the penultimate harbinger of death for many cancer patients. Bone metastases are often associated with fractures and severe pain resulting in decreased quality of life. Accordingly, effective therapies to inhibit the development or progression of bone metastases will have important clinical benefits. To achieve this goal understanding the mechanisms through which bone metastases develop and progress may provide targets to inhibit the metastases. In the past few years, there have been advances in both understanding the mechanisms through which bone metastases develop and how they impact bone remodeling. Additionally, gains in promising clinical strategies to target bone metastases have been developed. In this prospectus, we will discuss some of these advances. J. Cell. Biochem. 102: 1095-1102, 2007. (c) 2007 Wiley-Liss, Inc.
\end{abstract}

Key words: prostate cancer; breast cancer; SDF; CXCR4; BMP; Wnt; RANKL; PTHrP

Bone metastases can accompany any metastatic tumor type; however, certain tumors have a predisposition to forming bone metastases. These include breast cancer, prostate cancer, thyroid carcinoma, multiple myeloma, and renal cell carcinoma. Typically, metastases are osteolytic, that is, they resorb bone resulting in decreased bone mineral content. An exception to this rule is prostate cancer bone metastases as they have a combination of osteolytic activity and osteoblastic activity (i.e., induce bone mineral production). A small portion of patients with breast cancer bone metastases have primarily osteoblastic activity. Both osteolytic activity and osteoblastic activity result in weakening of the normal healthy bone and predispose the patient to a variety of skeletalrelated events.

The skeletal-related events associated with bone metastasis result in significant complications that diminish the quality of life in affected patients. These complications include bone pain, impaired mobility, pathological fracture,

Grant sponsor: National Cancer Institute; Grant numbers: P01 CA093900, R01 CA071672.

*Correspondence to: Evan T. Keller, RM 5308 CCGCB, 1500 East Medical Center Drive, Ann Arbor, MI 481090940. E-mail: etkeller@umich.edu

Received 15 July 2007; Accepted 18 July 2007

DOI 10.1002/jcb.21540

(c) 2007 Wiley-Liss, Inc. spinal cord compression, and symptomatic hypercalcemia [Galasko, 1986; Coleman, 1997; Moul and Lipo, 1999]. Despite advances in the diagnosis and management of primary localized cancers, advanced disease with skeletal metastasis remains incurable. Current therapeutic modalities are mostly palliative, and may include hormonal therapy, pharmacological management of bone pain, radiotherapy for pain and spinal cord compression [Szostak and Kyprianou, 2000], various chemotherapy regimens, and the use of bisphosphonates to inhibit osteoclast activity [Papapoulos et al., 2000]. Although these therapies may have palliative effects, they typically do not cure the cancer. Understanding the mechanisms that promote bone metastasis may help identify new therapeutic targets to stop the progression of this devastating aspect of cancer. We highlight several active areas of bone metastasis research below.

\section{CHEMOTAXIS}

Chemotaxis is a basic physiological process through which cells migrate along a chemical gradient. For example, hematopoietic stem cells (HSC) express the receptor for stromal-derived factor (SDF), CXCR4. Bone marrow is a source of SDF and HSC migrate down the chemotactic gradient to the bone marrow. Similar to the HSCs, it was observed that melanoma, breast cancer and prostate cancer cells express CXCR4 [Fourcin et al., 1996; Muller et al., 2001; 
Taichman et al., 2002], which allows them to target bone. Since these initial observations, it has been reported that many cancer types express CXCR4 and co-opt the HSC chemotactic system. SDF-1 promotes chemotaxis through upregulation of migration in the target cells [Libura et al., 2002]. In terms of prostate cancer, it has been reported that androgen receptor negatively affects regulation of CXCR4 [Akashi et al., 2006], which suggest that loss of androgen receptor enhances prostate cancer migration. This may be important to the development of metastasis because as prostate cancer progresses, androgen receptor expression is altered. In breast cancer, $\mathrm{NF} \kappa \mathrm{B}$ was shown to upregulate chemotaxis through inducing CXCR4 expression in breast cancer cells [Helbig et al., 2003]. $\mathrm{NF} \kappa \mathrm{B}$ activity is often upregulated secondary to inflammatory processes. Thus, this observation suggests that inflammation may promote metastasis through $\mathrm{NF} \kappa \mathrm{B}-$ mediated induction of CXCR4. As more research in this area is performed, it is likely that some of these mechanisms through which CXCR4 is regulated and promotes metastasis will be found relevant to multiple tumor types.

Due to its importance in the metastatic process, many efforts have been focused on targeting the CXCR4:SDF-1 axis. Towards this end, cancer investigators have taken advantage of the fact that human immunodeficiency virus (HIV) uses CXCR4 as a co-receptor and there is an armentarium of anti-HIV drugs that target CXCR4 activity [Juarez et al., 2004; Tsutsumi et al., 2007]. For example, T140, a peptide analog of CXCR4, was shown to decrease pulmonary metastasis in a murine model of breast cancer [Tamamura et al., 2003]. In another strategy, bisphosphonates, compounds that target osteoclasts, have been shown to decrease CXCR4 in breast [Denoyelle et al., 2003] and prostate cancer [Miwa et al., 2005]. As these compounds are developed and tested in clinics they may make an impact on cancer metastasis to bone.

\section{THE BONE MICROENVIRONMENT}

The final target site where metastatic cells grow and develop into clinically relevant metastases, termed the metastatic microenvironment, is clearly a key regulator of metastasis. This concept, first described as "the seed and soil" hypothesis by Paget [1829], posits that the metastatic microenvironment (i.e., the "soil") must contain the appropriate elements for cancer cells (i.e., the "seed") to establish clinically detectable metastases. This concept is supported by the findings that although tumor cells are often circulating throughout the body their presence does not predict the development of metastases [Morgan et al., 2007; Pfitzenmaier et al., 2007]. Additionally, the observation that specific tumor types favor specific metastatic sites further supports the specificity of metastatic niches. For example, colon cancer selectively metastasizes to liver [Zvibel et al., 2000 ] and prostate cancer preferentially metastasizes to bone [Shah et al., 2004]. Identifying the cellular and molecular components of the microenvironment that promote development of bone metastasis has identified targets to block the development of metastases.

\section{RECEPTOR ACTIVATOR OF NFKB LIGAND AND OSTEOPROTEGERIN}

The metastasis of prostate cancer to bone is accompanied by a disruption in the normal bone remodeling equilibrium, although the mechanisms through which this occurs are largely unknown at present. In healthy adults, the regulated destruction (resorption or lysis) of normal lamellar bone matrix by large multinucleated osteoclasts is tightly coupled to the consequent formation of new bone by osteoblasts, such that lysis and formation are balanced (reviewed in Manolagas and Jilka [1995]). However, in prostate cancer bone metastasis, bone lysis is stimulated at sites of tumor growth and excess woven bone is synthesized [Clarke et al., 1991]. This results in a general increase in both bone turnover and volume, although woven bone has less collagen and therefore less tensile strength than normal and is more susceptible to fracture. Evidence suggests that lysis is a prerequisite for the establishment of tumor cells in bone [Roland, 1958; Nielsen et al., 1991], therefore understanding the regulation of bone resorption may suggest mechanisms through which tumors can develop in bone and may indicate novel therapeutic targets.

In normal bone, osteoblastic cells regulate osteoclastogenesis and osteoclast activity by interacting with mononuclear hematopoietic osteoclast precursors [Roodman, 1996]. The molecular mediators of this interaction were 
shown to be the osteoblast-expressed proteins, osteoprotegerin (OPG) and receptor activator of $\mathrm{NF} \kappa \mathrm{B}$ ligand (RANKL). Binding of RANKL to the osteoclast precursor-expressed RANK initiates a cascade of intracellular signals that culminates in the acquisition and activation of the osteoclast phenotype [Lacey et al., 1998; Yasuda et al., 1998a]. The absolute requirement of this interaction for osteoclastogenesis was shown by the generation of transgenic rankl-/and rank-/- mice that developed severely hyperdense bones due to an absence of osteoclasts [Dougall et al., 1999; Kong et al., 1999]. Furthermore, administration of soluble extracellular RANKL to mice resulted in hypercalcemia and reduced bone volume, concomitant with a doubling of osteoclast size [Lacey et al., 1998]. The soluble glycoprotein OPG regulates excessive bone resorption by acting as a soluble decoy receptor for RANKL [Simonet et al., 1997], and therefore neutralizes its interaction with RANK, abrogating osteoclast formation, activation and survival in vitro [Yasuda et al., 1998a,b] and in vivo [Lacey et al., 1998]. The crucial role of OPG in bone remodeling was demonstrated using transgenic opg-/- mice, which showed uncontrolled bone resorption and severe osteoporosis [Mizuno et al., 1998]. These studies suggest that the balance between RANKL and OPG determines the extent of bone resorption, in that a relative decrease in OPG results in excessive resorption and a relative increase in OPG inhibits resorption.

Expression of OPG, RANKL and/or RANK are dysregulated in a number of cancers in bone, including osteoclastoma [Atkins et al., 2000], breast cancer [Lau et al., 2006; Kapoor et al., 2007] and prostate cancer [Brown et al., 2001; Perez-Martinez et al., 2007], suggesting that these proteins may be involved in tumormediated bone destruction. In the case of breast cancers, it appears they express OPG and RANK but not RANKL [Thomas et al., 1999] or that RANKL expression is inversely related to estrogen receptor expression [Cross et al., 2006]. However, co-culture with hematopoietic bone marrow cells and osteoblasts resulted in a net increase in RANKL expression, suggesting an indirect mechanism through which localized bone lysis may occur in breast cancer bone metastasis, by activation of osteoclast precursors [Thomas et al., 1999]. This was supported using a murine in vitro model in which interactions between mouse breast cancer cells and bone marrow cells similarly resulted in a net increase in RANKL activity [Chikatsu et al., 2000]. Furthermore, it has been suggested that breast cancer can induced tumor-associated macrophages (TAMs) to differentiate into osteoclasts through RANKL-dependent and -independent mechanisms [Lau et al., 2006]. The cancer-stromal interaction is also critical in multiple myeloma, where co-culture produced a net increase in RANKL expression and in osteoclastogenesis that was inhibited by addition of soluble RANK [Pearse et al., 2001]. The production of active soluble RANKL by prostate cancer cells in vitro has been implicated as a mechanism through which prostate cancer cells can directly initiate osteoclastogenesis and therefore stimulate bone resorption [Zhang et al., 2001].

Several exciting and provocative studies have examined the therapeutic uses of soluble RANK and OPG in the treatment of hematological and solid tumors in bone [Dougall and Chaisson, 2006b]. As a fusion protein with human IgG, RANK has proven efficacious in the inhibition of bone resorption in a mouse model of humoral hypercalcemia of malignancy as induced by PTHrP administration [Oyajobi et al., 2001], and in the prevention of myeloma-induced osteoclastic bone destruction in a SCID-human model [Pearse et al., 2001] and prostate cancer model [Zhang et al., 2003]. In vitro experiments treating osteoclastoma-derived cells with OPG reduced the number of mature osteoclasts and inhibited bone resorption [Atkins et al., 2001]. Dramatic decreases in the numbers of mature osteoclasts and in the size and/or number of lesions in bone were observed following the treatment with OPG of mice carrying human breast cancer cells [Morony et al., 2001], murine multiple myeloma [Croucher et al., 2001], and human prostate cancer cells [Zhang et al., 2001]. In human prostate cancer cells, OPG has been shown to be a survival factor through its ability to inhibit TRAIL-mediated apoptosis [Holen et al., 2002]. These studies suggest that in bone metastatic tumors, inhibition of the primary resorptive stage may be sufficient to inhibit tumor establishment and halt progression of disease, even in those tumors that have primarily an osteoblastic phenotype. Importantly, treatment with OPG has also been demonstrated to block pain-related behavior in mice carrying bone cancers [Honore et al., 2000; Luger et al., 2001]. Development of OPG peptide 
mimetics may also offer some promise to sequester RANKL activity [Heath et al., 2007]. Although these previous studies provide proof of concept that blocking RANKL can impact skeletal metastasis, currently, the most likely clinical candidate to target RANKL is Denosumab (AMG 162), a fully human monoclonal antibody that can bind and inhibit human RANKL [Dougall and Chaisson, 2006a]. A phase 1 clinical trial in patients with multiple myeloma or breast carcinoma with bone metastases showed that a single subcutaneous injection of denosumab caused rapid and sustained suppression of bone turnover markers and was well tolerated. While studies are at an early stage at present, it appears that therapeutic targeting of the OPG/RANKL/RANK proteins holds great promise for treatment of bone metastases.

\section{BISPHOPHONATES}

Bisphosphonates are a group of chemicals that inhibit osteoclast activity resulting in decreased bone resorption and thus have received much attention as inhibitors of clinical complications of bone metastases [Mundy, 1999; Diel et al., 2000; Major et al., 2000]. Bisphosphonates work directly on osteoclasts to induce their apoptosis [Fleisch, 1997; Rowe et al., 1999]. Animal studies have demonstrated that bisphosphonates can diminish tumor-induced osteoclastogenesis and osteolysis [Hall and Stoica, 1994; Yoneda et al., 1997, 2000; Kurth et al., 2000; Clohisy et al., 2001]. Although, in some instances, it appears to only reduce tumor-induced lysis, but not tumor burden [Dallas et al., 1999]. Studies in breast cancer and myeloma patients have shown that these agents markedly inhibit the progression of bone disease resulting in improved survival and decreased morbidity from bone pain and fracture [Apperley and Croucher, 1999; Lipton, 2000]. These results have led to their incorporation into standard treatment regimens for skeletal metastases associated with these cancers.

In addition to inhibiting osteoclast survival, bisphosphonates may have direct effects on tumor cells [Shipman et al., 1998b]. For example, several bisphosphonates induce apoptosis in myeloma cells [Aparicio et al., 1998; Shipman et al., 1998a; Takahashi et al., 2001]. However, this is not the case for all bisphosphonates [Shipman et al., 2000]. In addition to inducing apoptosis, bisphosphonates have been shown to inhibit breast carcinoma cell adhesion to bone
[Magnetto et al., 1999]. Furthermore, alendronate blocked collagen degradation and MMP release from prostate cancer cells [Stearns, 1998; Stearns and Wang, 1998]. Taken together, these findings suggest that bisphosphonate action is not limited to inhibition of osteoclasts.

Studies of bisphosphonates use in patients with prostate cancer skeletal metastases have generally shown a decrease in bone pain although some studies have shown no benefit [Harvey and Lipton, 1996; Pelger et al., 1998; Heidenreich et al., 2001]. A recent randomized study of the oral bisphosphonate clodronate showed an encouraging decrease in the rate of progression to symptomatic bone metastases in men with prostate cancer [Fernandez-Conde et al., 1997]. Consistent with this observation is the finding that zoledronic acid is a third generation bisphosphonate that has demonstrated significantly increased activity in preclinical models when compared to early agents in this class. Exposure of prostate cancer cell lines to zoledronic acid results in marked inhibition of cell proliferation suggesting that this agent may have a direct antitumor effect beyond its ability to inhibit osteoclast activity [Coleman, 2000; Dearnaley and Sydes, 2001]. Zoledronic acid also has been shown to inhibit the invasion of prostate carcinoma cell lines in vitro [Boissier et al., 2000]. Clinical studies have demonstrated efficacy in treating hypercalcemia of malignancy, leading to recent FDA approval for use in this clinical setting [Major et al., 2001]. Treatment with zoledronic acid results in a significant and sustained decrease in markers of bone metabolism. However, osteonecrosis of the jaw (ONJ) has been recognized as a serious complication of bisphosphonate therapy [Mortensen et al., 2007]. It is not clear if this is due to generalized inhibition of osteoclast activity induced by bisphosphonates, in which case inhibition of RANKL may also cause ONJ, or if this is specific to bisphosphonates. It has been suggested that prior existing dental pathology may underlie some of the ONJ cases, but this is not clearly known [Dunstan et al., 2007].

\section{SUMMARY}

Bone metastases are a severe consequence of many cancers. Advances in the biology of bone metastases have led to new therapies that target their establishment and progression in animal models. These therapies have proven 
efficacious in certain clinical circumstances and many are undergoing evaluation in clinical trials. The majority of therapies are targeted at inhibiting the osteolytic activity induced by the cancer; however, others, such as inhibition of SDF-1 activity, are directed at inhibiting various components of the metastatic cascade such as migration. In some instances, therapies, such as chronic bisphosphonate administration, may actually have severe clinical consequences indicating the need to continually increase our understanding of the pathophysiology of bone metastasis and the need to continue developing improved therapeutics. Additional research in the area of mechanisms of bone metastasis may lead to additional promising therapies in the future.

\section{ACKNOWLEDGMENTS}

The breadth of research now being performed in bone metastasis is impossible to summarize in this articles, so we apologize in advance to the many investigators whose outstanding work we could not cite due to space limitations.

\section{REFERENCES}

Akashi T, Koizumi K, Nagakawa O, Fuse H, Saiki I. 2006. Androgen receptor negatively influences the expression of chemokine receptors (CXCR4, CCR1) and ligandmediated migration in prostate cancer DU-145. Oncol Rep 16:831-836.

Aparicio A, Gardner A, Tu Y, Savage A, Berenson J, Lichtenstein A. 1998. In vitro cytoreductive effects on multiple myeloma cells induced by bisphosphonates. Leukemia 12:220-229.

Apperley JF, Croucher PI. 1999. Bisphosphonates in multiple myeloma. Pathol Biol (Paris) 47:178-181.

Atkins GJ, Haynes DR, Graves SE, Evdokiou A, Hay S, Bouralexis S, Findlay DM. 2000. Expression of osteoclast differentiation signals by stromal elements of giant cell tumors. J Bone Miner Res 15:640-649.

Atkins GJ, Bouralexis S, Haynes DR, Graves SE, Geary SM, Evdokiou A, Zannettino AC, Hay S, Findlay DM. 2001. Osteoprotegerin inhibits osteoclast formation and bone resorbing activity in giant cell tumors of bone. Bone 28:370-377.

Boissier S, Ferreras M, Peyruchaud O, Magnetto S, Ebetino FH, Colombel M, Delmas P, Delaisse JM, Clezardin P. 2000. Bisphosphonates inhibit breast and prostate carcinoma cell invasion, an early event in the formation of bone metastases. Cancer Res 60:2949-2954.

Brown JM, Corey E, Lee ZD, True LD, Yun TJ, Tondravi M, Vessella RL. 2001. Osteoprotegerin and rank ligand expression in prostate cancer. Urology 57:611-616.

Chikatsu N, Takeuchi Y, Tamura Y, Fukumoto S, Yano K, Tsuda E, Ogata E, Fujita T. 2000. Interactions between cancer and bone marrow cells induce osteoclast differentiation factor expression and osteoclast-like cell formation in vitro. Biochem Biophys Res Commun 267:632-637.

Clarke NW, McClure J, George NJ. 1991. Morphometric evidence for bone resorption and replacement in prostate cancer. Br J Urol 68:74-80.

Clohisy DR, PF OK, Ramnaraine ML. 2001. Pamidronate decreases tumor-induced osteoclastogenesis in osteopetrotic mice. J Orthop Res 19:554-558.

Coleman RE. 1997. Skeletal complications of malignancy. Cancer 80:1588-1594

Coleman RE. 2000. Optimising treatment of bone metastases by Aredia(TM) and Zometa(TM). Breast Cancer 7:361-369.

Cross SS, Harrison RF, Balasubramanian SP, Lippitt JM, Evans CA, Reed MW, Holen I. 2006. Expression of receptor activator of nuclear factor kappabeta ligand (RANKL) and tumour necrosis factor related, apoptosis inducing ligand (TRAIL) in breast cancer, and their relations with osteoprotegerin, oestrogen receptor, and clinicopathological variables. J Clin Pathol 59:716-720.

Croucher PI, Shipman CM, Lippitt J, Perry M, Asosingh K, Hijzen A, Brabbs AC, van Beek EJ, Holen I, Skerry TM, Dunstan CR, Russell GR, Van Camp B, Vanderkerken K. 2001. Osteoprotegerin inhibits the development of osteolytic bone disease in multiple myeloma. Blood 98:35343540 .

Dallas SL, Garrett IR, Oyajobi BO, Dallas MR, Boyce BF, Bauss F, Radl J, Mundy GR. 1999. Ibandronate reduces osteolytic lesions but not tumor burden in a murine model of myeloma bone disease. Blood 93:1697-1706.

Dearnaley D, Sydes M. 2001. Preliminary evidence that oral clodronate delays symptomatic progression of bone metastases from prostate cancer: First results of the MRC Pr05 Trial. Proc Am Soc Clin Oncol Annual Meeting 20:693.

Denoyelle C, Hong L, Vannier JP, Soria J, Soria C. 2003. New insights into the actions of bisphosphonate zoledronic acid in breast cancer cells by dual RhoA-dependent and -independent effects. Br J Cancer 88:1631-1640.

Diel IJ, Solomayer E, Bastert G. 2000. Bisphosphonates and the prevention of metastasis. Cancer 88:3080-3088

Dougall W, Chaisson M. 2006a. Monoclonal antibody targeting RANKL as a therapy for cancer-induced bone diseases. Clin Calcium 16:627-635.

Dougall WC, Chaisson M. 2006b. The RANK/RANKL/OPG triad in cancer-induced bone diseases. Cancer Metastasis Rev 25:541-549.

Dougall WC, Glaccum M, Charrier K, Rohrbach K, Brasel K, De Smedt T, Daro E, Smith J, Tometsko ME, Maliszewski CR, Armstrong A, Shen V, Bain S, Cosman D, Anderson D, Morrissey PJ, Peschon JJ, Schuh J. 1999. RANK is essential for osteoclast and lymph node development. Genes Dev 13:2412-2424.

Dunstan CR, Felsenberg D, Seibel MJ. 2007. Therapy insight: The risks and benefits of bisphosphonates for the treatment of tumor-induced bone disease. Nat Clin Pract Oncol 4:42-55.

Fernandez-Conde M, Alcover J, Aaron JE, Ordi J, Carretero P. 1997. Skeletal response to clodronate in prostate cancer with bone metastases. Am J Clin Oncol 20:471476.

Fleisch H. 1997. Mechanisms of action of the bisphosphonates. Medicina (B Aires) 57 (Suppl 1):65-75. 
Fourcin M, Chevalier S, Guillet C, Robledo O, Froger J, Pouplard-Barthelaix A, Gascan H. 1996. gp130 transducing receptor cross-linking is sufficient to induce interleukin-6 type responses. J Biol Chem 271:1175611760.

Galasko CS. 1986. Skeletal metastases. Clin Orthop Relat Res 210:18-30.

Hall DG, Stoica G. 1994. Effect of the bisphosphonate risedronate on bone metastases in a rat mammary adenocarcinoma model system. J Bone Miner Res 9: 221-230.

Harvey HA, Lipton A. 1996. The role of bisphosphonates in the treatment of bone metastases-The U.S. experience. Support Care Cancer 4:213-217.

Heath DJ, Vanderkerken K, Cheng X, Gallagher O, Prideaux M, Murali R, Croucher PI. 2007. An osteoprotegerin-like peptidomimetic inhibits osteoclastic bone resorption and osteolytic bone disease in myeloma. Cancer Res 67:202-208.

Heidenreich A, Hofmann R, Engelmann UH. 2001. The use of bisphosphonate for the palliative treatment of painful bone metastasis due to hormone refractory prostate cancer [In Process Citation]. J Urol 165:136-140.

Helbig G, Christopherson KW II, Bhat-Nakshatri P, Kumar S, Kishimoto H, Miller KD, Broxmeyer HE, Nakshatri H. 2003. NF-kappaB promotes breast cancer cell migration and metastasis by inducing the expression of the chemokine receptor CX CR4. J Biol Chem 278: 21631-21638.

Holen I, Croucher PI, Hamdy FC, Eaton CL. 2002. Osteoprotegerin (OPG) is a survival factor for human prostate cancer cells. Cancer Res 62:1619-1623.

Honore P, Luger NM, Sabino MA, Schwei MJ, Rogers SD, Mach DB, O'Keefe PF, Ramnaraine ML, Clohisy DR, Mantyh PW. 2000. Osteoprotegerin blocks bone cancerinduced skeletal destruction, skeletal pain and painrelated neurochemical reorganization of the spinal cord. Nat Med 6:521-528.

Juarez J, Bendall L, Bradstock K. 2004. Chemokines and their receptors as therapeutic targets: The role of the SDF-1/CXCR4 axis. Curr Pharm Des 10:1245-1259.

Kapoor P, Suva LJ, Welch DR, Donahue HJ. 2007. Osteoprotegrin and the bone homing and colonization potential of breast cancer cells. J Cell Biochem

Kong YY, Yoshida H, Sarosi I, Tan HL, Timms E, Capparelli C, Morony S, Oliveira-dos-Santos AJ, Van G, Itie A, Khoo W, Wakeham A, Dunstan CR, Lacey DL, Mak TW, Boyle WJ, Penninger JM. 1999. OPGL is a key regulator of osteoclastogenesis, lymphocyte development and lymph-node organogenesis. Nature 397:315323.

Kurth AH, Kim SZ, Sedlmeyer I, Hovy L, Bauss F. 2000. Treatment with ibandronate preserves bone in experimental tumour-induced bone loss. J Bone Joint Surg Br 82:126-130.

Lacey DL, Timms E, Tan HL, Kelley MJ, Dunstan CR, Burgess T, Elliott R, Colombero A, Elliott G, Scully S, Hsu H, Sullivan J, Hawkins N, Davy E, Capparelli C, Eli A, Qian YX, Kaufman S, Sarosi I, Shalhoub V, Senaldi G, Guo J, Delaney J, Boyle WJ. 1998. Osteoprotegerin ligand is a cytokine that regulates osteoclast differentiation and activation. Cell 93:165-176.

Lau YS, Danks L, Sun SG, Fox S, Sabokbar A, Harris A, Athanasou NA. 2006. RANKL-dependent and RANKL- independent mechanisms of macrophage-osteoclast differentiation in breast cancer. Breast Cancer Res Treat

Libura J, Drukala J, Majka M, Tomescu O, Navenot JM, Kucia M, Marquez L, Peiper SC, Barr FG, JanowskaWieczorek A, Ratajczak MZ. 2002. CXCR4-SDF-1 signaling is active in rhabdomyosarcoma cells and regulates locomotion, chemotaxis, and adhesion. Blood 100:25972606.

Lipton A. 2000. Bisphosphonates and breast carcinoma: Present and future. Cancer 88:3033-3037.

Luger NM, Honore P, Sabino MA, Schwei MJ, Rogers SD, Mach DB, Clohisy DR, Mantyh PW. 2001. Osteoprotegerin diminishes advanced bone cancer pain. Cancer Res 61:4038-4047.

Magnetto S, Boissier S, Delmas PD, Clezardin P. 1999. Additive antitumor activities of taxoids in combination with the bisphosphonate ibandronate against invasion and adhesion of human breast carcinoma cells to bone. Int J Cancer 83:263-269.

Major PP, Lipton A, Berenson J, Hortobagyi G. 2000. Oral bisphosphonates: A review of clinical use in patients with bone metastases. Cancer 88:6-14.

Major P, Lortholary A, Hon J, Abdi E, Mills G, Menssen HD, Yunus F, Bell R, Body J, Quebe-Fehling E, Seaman J. 2001. Zoledronic acid is superior to pamidronate in the treatment of hypercalcemia of malignancy: A pooled analysis of two randomized, controlled clinical trials. J Clin Oncol 19:558-567.

Manolagas SC, Jilka RL. 1995. Bone marrow, cytokines, and bone remodeling. Emerging insights into the pathophysiology of osteoporosis. N Engl J Med 332:305-311.

Miwa S, Mizokami A, Keller ET, Taichman R, Zhang J, Namiki M. 2005. The bisphosphonate YM529 inhibits osteolytic and osteoblastic changes and CXCR-4-induced invasion in prostate cancer. Cancer Res 65:8818-8825.

Mizuno A, Amizuka N, Irie K, Murakami A, Fujise N, Kanno T, Sato Y, Nakagawa N, Yasuda H, Mochizuki S, Gomibuchi T, Yano K, Shima N, Washida N, Tsuda E, Morinaga T, Higashio K, Ozawa H. 1998. Severe osteoporosis in mice lacking osteoclastogenesis inhibitory factor/osteoprotegerin. Biochem Biophys Res Commun 247:610-615.

Morgan TM, Lange PH, Vessella RL. 2007. Detection and characterization of circulating and disseminated prostate cancer cells. Front Biosci 12:3000-3009.

Morony S, Capparelli C, Sarosi I, Lacey DL, Dunstan CR, Kostenuik PJ. 2001. Osteoprotegerin inhibits osteolysis and decreases skeletal tumor burden in syngeneic and nude mouse models of experimental bone metastasis. Cancer Res 61:4432-4436.

Mortensen M, Lawson W, Montazem A. 2007. Osteonecrosis of the jaw associated with bisphosphonate use: Presentation of seven cases and literature review. Laryngoscope 117:30-34.

Moul JW, Lipo DR. 1999. Prostate cancer in the late 1990s: Hormone refractory disease options. Urol Nurs 19:125131; quiz 132-133.

Muller A, Homey B, Soto H, Ge N, Catron D, Buchanan ME, McClanahan T, Murphy E, Yuan W, Wagner SN, Barrera JL, Mohar A, Verastegui E, Zlotnik A. 2001. Involvement of chemokine receptors in breast cancer metastasis. Nature 410:50-56.

Mundy GR. 1999. Bisphosphonates as anticancer drugs. Expert Opin Investig Drugs 8:2009-2015. 
Nielsen OS, Munro AJ, Tannock IF. 1991. Bone metastases: Pathophysiology and management policy. J Clin Oncol 9:509-524.

Oyajobi BO, Anderson DM, Traianedes K, Williams PJ, Yoneda T, Mundy GR. 2001. Therapeutic efficacy of a soluble receptor activator of nuclear factor kappaB-IgG Fc fusion protein in suppressing bone resorption and hypercalcemia in a model of humoral hypercalcemia of malignancy. Cancer Res 61:2572-2578.

Paget S. 1829. The distribution of secondary growth in cancer of the breast. Lancet 1:571-573.

Papapoulos SE, Hamdy NA, van der Pluijm G. 2000. Bisphosphonates in the management of prostate carcinoma metastatic to the skeleton. Cancer 88:3047-3053.

Pearse RN, Sordillo EM, Yaccoby S, Wong BR, Liau DF, Colman N, Michaeli J, Epstein J, Choi Y. 2001. Multiple myeloma disrupts the TRANCE/osteoprotegerin cytokine axis to trigger bone destruction and promote tumor progression. Proc Natl Acad Sci USA 98:11581-11586.

Pelger RC, Hamdy NA, Zwinderman AH, Lycklama a Nijeholt AA, Papapoulos SE. 1998. Effects of the bisphosphonate olpadronate in patients with carcinoma of the prostate metastatic to the skeleton. Bone 22:403408.

Perez-Martinez FC, Alonso V, Sarasa JL, Nam-Cha SG, Vela-Navarrete R, Manzarbeitia F, Calahorra FJ, Esbrit P. 2007. Immunohistochemical analysis of low-grade and high-grade prostate carcinoma: Relative changes of parathyroid hormone-related protein and its parathyroid hormone 1 receptor, osteoprotegerin and receptor activator of nuclear factor-kB ligand. J Clin Pathol 60:290294.

Pfitzenmaier J, Ellis WJ, Hawley S, Arfman EW, Klein JR, Lange PH, Vessella RL. 2007. The detection and isolation of viable prostate-specific antigen positive epithelial cells by enrichment: A comparison to standard prostatespecific antigen reverse transcriptase polymerase chain reaction and its clinical relevance in prostate cancer. Urol Oncol 25:214-220.

Roland S. 1958. Calcium studies in ten cases of osteoblastic prostatic metastasis. J Urol 79:339-342.

Roodman GD. 1996. Advances in bone biology: The osteoclast. Endocrine Rev 17:308-332.

Rowe DJ, Etre LA, Lovdahl MJ, Pietrzyk DJ. 1999. Relationship between bisphosphonate concentration and osteoclast activity and viability. In Vitro Cell Dev Biol Anim 35:383-388.

Shah RB, Mehra R, Chinnaiyan AM, Shen R, Ghosh D, Zhou M, Macvicar GR, Varambally S, Harwood J, Bismar TA, Kim R, Rubin MA, Pienta KJ. 2004. Androgenindependent prostate cancer is a heterogeneous group of diseases: Lessons from a rapid autopsy program. Cancer Res 64:9209-9216.

Shipman CM, Croucher PI, Russell RG, Helfrich MH, Rogers MJ. 1998a. The bisphosphonate incadronate (YM175) causes apoptosis of human myeloma cells in vitro by inhibiting the mevalonate pathway. Cancer Res 58:5294-5297.

Shipman CM, Rogers MJ, Apperley JF, Graham R, Russell G, Croucher PI. 1998b. Anti-tumour activity of bisphosphonates in human myeloma cells. Leuk Lymphoma 32:129-138.

Shipman CM, Vanderkerken K, Rogers MJ, Lippitt JM, Asosingh K, Hughes DE, Van Camp B, Russell RG,
Croucher PI. 2000. The potent bisphosphonate ibandronate does not induce myeloma cell apoptosis in a murine model of established multiple myeloma. $\mathrm{Br} \mathrm{J}$ Haematol 111:283-286.

Simonet WS, Lacey DL, Dunstan CR, Kelley M, Chang MS, Luthy R, Nguyen HQ, Wooden S, Bennett L, Boone T, Shimamoto G, DeRose M, Elliott R, Colombero A, Tan HL, Trail G, Sullivan J, Davy E, Bucay N, Renshaw-Gegg L, Hughes TM, Hill D, Pattison W, Campbell P, Boyle WJ, et al. 1997. Osteoprotegerin: A novel secreted protein involved in the regulation of bone density. Cell 89:309319 .

Stearns ME. 1998. Alendronate blocks TGF-beta1 stimulated collagen 1 degradation by human prostate PC-3 ML cells. Clin Exp Metastasis 16:332-339.

Stearns ME, Wang M. 1998. Alendronate blocks metalloproteinase secretion and bone collagen I release by PC-3 ML cells in SCID mice. Clin Exp Metastasis 16: 693-702.

Szostak MJ, Kyprianou N. 2000. Radiation-induced apoptosis: Predictive and therapeutic significance in radiotherapy of prostate cancer (review). Oncol Rep 7: 699-706.

Taichman RS, Cooper C, Keller ET, Pienta KJ, Taichman NS, McCauley LK. 2002. Use of the stromal cell-derived factor-1/CXCR4 pathway in prostate cancer metastasis to bone. Cancer Res 62:1832-1837.

Takahashi R, Shimazaki C, Inaba T, Okano A, Hatsuse M, Okamoto A, Hirai H, Ashihara E, Nakagawa M. 2001. A newly developed bisphosphonate, YM529, is a potent apoptosis inducer of human myeloma cells. Leuk Res 25 : 77-83.

Tamamura H, Hori A, Kanzaki N, Hiramatsu K, Mizumoto M, Nakashima H, Yamamoto N, Otaka A, Fujii N. 2003. T140 analogs as CXCR4 antagonists identified as antimetastatic agents in the treatment of breast cancer. FEBS Lett 550:79-83.

Thomas RJ, Guise TA, Yin JJ, Elliott J, Horwood NJ, Martin TJ, Gillespie MT. 1999. Breast cancer cells interact with osteoblasts to support osteoclast formation. Endocrinology 140:4451-4458.

Tsutsumi H, Tanaka T, Ohashi N, Masuno H, Tamamura H, Hiramatsu K, Araki T, Ueda S, Oishi S, Fujii N. 2007. Therapeutic potential of the chemokine receptor CXCR4 antagonists as multifunctional agents. Biopolymers 88: 279-289.

Yasuda H, Shima N, Nakagawa N, Mochizuki SI, Yano K, Fujise N, Sato Y, Goto M, Yamaguchi K, Kuriyama M, Kanno T, Murakami A, Tsuda E, Morinaga T, Higashio K. 1998a. Identity of osteoclastogenesis inhibitory factor (OCIF) and osteoprotegerin (OPG): A mechanism by which OPG/OCIF inhibits osteoclastogenesis in vitro. Endocrinology 139:1329-1337.

Yasuda H, Shima N, Nakagawa N, Yamaguchi K, Kinosaki M, Mochizuki S, Tomoyasu A, Yano K, Goto M, Murakami A, Tsuda E, Morinaga T, Higashio K, Udagawa N, Takahashi N, Suda T. 1998b. Osteoclast differentiation factor is a ligand for osteoprotegerin/ osteoclastogenesis-inhibitory factor and is identical to TRANCE/RANKL. Proc Natl Acad Sci USA 95:35973602.

Yoneda T, Sasaki A, Dunstan C, Williams PJ, Bauss F, De Clerck YA, Mundy GR. 1997. Inhibition of osteolytic bone metastasis of breast cancer by combined treatment with 
the bisphosphonate ibandronate and tissue inhibitor of the matrix metalloproteinase-2. J Clin Invest 99:2509-2517.

Yoneda T, Michigami T, Yi B, Williams PJ, Niewolna M, Hiraga T. 2000. Actions of bisphosphonate on bone metastasis in animal models of breast carcinoma. Cancer 88:2979-2988.

Zhang J, Dai J, Qi Y, Lin DL, Smith P, Strayhorn C, Mizokami A, Fu Z, Westman J, Keller ET. 2001. Osteoprotegerin inhibits prostate cancer-induced osteo- clastogenesis and prevents prostate tumor growth in the bone. J Clin Invest 107:1235-1244.

Zhang J, Dai J, Yao Z, Lu Y, Dougall W, Keller ET. 2003. Soluble receptor activator of nuclear factor kappaB Fc diminishes prostate cancer progression in bone. Cancer Res 63:7883-7890.

Zvibel I, Mintz Y, Brill S, Halpern Z, Papa M. 2000. The role of the liver environment in the regulation of colon cancer metastasis. Isr Med Assoc J 2:48-51. 